\title{
COMUNICAÇÃO E EDUCAÇÃO: ALÉM DE FORMA E CONTEÚDO
}

\author{
Autor: Laan Mendes de Barros \\ Doutor em Ciências da Comunicação pela ECA-USP, com pós-doutorado pela \\ Université Stendhal - Grenoble 3 \\ Professor do Programa de Pós-Graduação em Comunicação Social da \\ Universidade Metodista de São Paulo
}

Quando pensamos em distâncias e saberes na sociedade contemporânea precisamos reconhecer que ambos já não têm as mesmas dimensões de tempos passados. As distâncias são relativas e sua percepção depende das tecnologias de informação e comunicação disponíveis e dos sistemas de transporte com os quais se conta. Os saberes, embora difusos e fragmentados, são cada vez mais amplos e diversificados e estão em constante transformação, em razão dos mesmos avanços tecnológicos que imprimem novas formas de pensar, que implicam em captar, sistematizar, armazenar e representar informações e conhecimentos de forma mais complexa e dinâmica. A convergência tecnológica que caracteriza este início de século dá à cultura uma natureza híbrida, refletida na polifonia dos discursos sobre a contemporaneidade. Este artigo é mais um desses discursos; que não pretende ser síntese final entre teses e antíteses, mas que se apresenta em uma perspectiva dialética, aberta ao diálogo e à construção de novas sínteses.

A comunicação e a educação estão presentes de maneira estruturante na sociedade desde os tempos mais remotos. A ação do ser humano na natura, produzindo cultura, passa necessariamente por processos de aprendizagem e construção de conhecimentos, de fluxos de informação e produção de sentidos. Isso fica ainda mais evidente e relevante na contemporaneidade, onde o fluxo de informações se vê intensificado e os conhecimentos estão em constante evolução, o que implica na revisão, superação de saberes antes aceitos e na construção de outros que se apliquem aos novos cenários que se descortinam. Vivemos um tempo de alargamento dos continentes culturais e rompimento de fronteiras disciplinares.

A compreensão dos processos educacionais e dos sistemas comunicacionais já não pode ser construída a partir de sua fragmentação, a partir de sua divisão em pedaços a serem tratados isoladamente por esta ou aquela disciplina dentre as áreas do conhecimento. Se a problemática a ser compreendida se apresenta de maneira multifacetada, híbrida e fluída, em constante transformação, faz-se necessário analisá-la, também, desde uma perspectiva complexa. As novas 
estratégias de estudo apontam para a pluralidade disciplinar, que pode, até mesmo, ultrapassar o nível da interdisciplinaridade, em abordagens transdisciplinares ${ }^{1}$.

Frente às tecnologias digitais contemporâneas, alguns ainda se mostram resistentes. Outros assumem uma postura de entusiasmo, ou mesmo de fascinação, em relação às "maravilhosas" máquinas e recursos disponíveis ao ser humano. Na linha da aceitação das tecnologias contemporâneas procura-se encarar os novos meios de comunicação e informação com naturalidade, como instrumentos de trabalho, presentes no cotidiano. Vale lembrar, no entanto, que eles não são meras ferramentas. Não podemos encará-los de maneira utilitária, separando forma e conteúdo, fazer e pensar. A presença de novas mídias em nosso cotidiano implica na mudança de escala de valores, demandando redefinição de conceitos, em uma nova compreensão dos sistemas, da vida em sociedade e do próprio fazer científico. Em especial, a educação ganha novas dimensões no "espaço elástico",2 que caracteriza a contemporaneidade. Os saberes se abrem e se estendem nas distâncias, hoje relativas por conta das tecnologias digitais e das redes de telecomunicações.

Para a academia ainda é difícil equacionar esse debate. Como acompanhar cientificamente a evolução tecnológica se a sua velocidade é maior que nossa capacidade de reflexão e sistematização? Por certo, sua abordagem não pode ficar restrita ao universo das ciências exatas, ao campo das Engenharias. Sua presença em nosso dia-a-dia implica desdobramentos na organização social e no comportamento humano. Portanto, aqueles mais voltados às questões das humanidades também devem se ocupar do estudo dessas novas tecnologias.

\section{Somar ou dividir?}

A lógica Cartesiana da divisão - "dividir cada dificuldade a ser examinada em tantas partes quanto possível e necessário para resolvê-las" ${ }^{3}$ - da especialização cada vez maior das disciplinas, em busca da objetividade e da sistematização, parece não mais ser suficiente para explicar as intrincadas relações do ser humano em sociedade. Especialmente quando esta sociedade está estruturada em uma imensa rede de tecnologias de informação e comunicação. Já

\footnotetext{
${ }^{1}$ Vários autores contemporâneos têm abordado a transdisciplinaridade. Lembramos aqui de Miguel Moragas Spa, ao tratar os direcionamentos epistemológicos dos estudos de Comunicação Social, e, especialmente, de Edgar Morin, em seus trabalhos sobre a complexidade.

${ }^{2}$ O termo "espaço elástico" é usado por Pierre Lévy, em seu livro Cibercultura, para denominar as transformações do espaço prático, quando percebido por meio de novas tecnologias de comunicação e de transporte.

${ }^{3}$ René Descartes, Discurso sobre o Método, Hemus, p. 40.
} 
não nos basta o paradigma cientificista, onde se supõe que o desenvolvimento do conhecimento é da competência exclusiva das ciências. A técnica, as artes e a filosofia também devem comparecer na elucidação dos nossos questionamentos.

Neste sentido, Edgar Morin chama a atenção para o fato de que "há, no estado atual, insuficiência da filosofia sozinha, insuficiência da ciência sozinha para conhecer o conhecimento", acrescentando que: "não se pode deixar o conhecimento cindir-se entre as concepções redutoras que cada disciplina segrega", Ele adverte:

\begin{abstract}
Dada a multidimensionalidade dos caracteres do conhecimento e a complexidade dos problemas que ela levanta, é necessário efectuar o difícil diálogo entre reflexão subjetiva e o conhecimento objetivo. Não é nossa intenção elaborar uma metaciência ou metafilosofia (há muito tempo que se tenta "superar" a filosofia numa pseudociência e a ciência numa pobre filosofia). Antes tentaremos trabalhar entre/com/para/contra a filosofia exangue e a ciência louca: contra a anemia de uma e pletora da outra, contra a sua clausura mútua e contra as carências ou mutilações que daí resultam, com as virtudes insubstituíveis da actividade científica (insaciável prospecção no universo desconhecido, diálogo cerrado com os fenômenos através de verificações/refutações); com a virtude insubstituível da actividade filosófica (a união da reflexão e da especulação); com a vontade firme de não sacrificar a objetividade à especulação, de não sacrificar a reflexão à operacionalidade. Se o olhar filosófico dá o recuo necessário para considerar a ciência, o olhar científico dá o recuo necessário para considerar a filosofia. Assim, a sua dialógica binocular poderia dar o novo recuo que nos é necessário para considerar o conhecimento. Este recuo seria o de um pensamento, à altura da complexidade e da multidimensionalidade do problema, e, a partir daí, ciência e filosofia poderiam aparecer-nos como dois rostos diferentes e complementares do mesmo: o pensamento 5 .
\end{abstract}

Seguindo a mesma linha, Laerthe Abreu Jr. lembra que nos últimos 300 anos "relegamos para segundo plano vivências e percepções que dificilmente se enquadram nesse esquema científico. Qual a medida para o afeto? Quais as classificações científicas para o prazer?" 6 Ele argumenta que "entender a ciência como portadora exclusiva de verdade é um dogma tão eficiente como a explicação mágica da realidade".

Para se pensar a inter-relação comunicação / educação é necessário partir, então, de uma visão mais aberta do que é o pensar-fazer acadêmico, não assumindo a objetividade como uma obsessão, como se a sua presença no exercício da pesquisa fosse algo possível de forma absoluta. Se o sujeito que pesquisa e o objeto da pesquisa se sobrepõem, como esperar absoluta

\footnotetext{
${ }^{4}$ Edgar Morin, O Método III: O Conhecimento do Conhecimento, p. 24

5 idem ibidem, p. 24

${ }^{6}$ Laerthe Abreu Jr, Conhecimento Transdisciplinar - O Cenário Epistemológico da Complexidade, p. 16.
} 
objetividade? Desta forma, fica inviável a imparcialidade e temos que admitir a presença da ideologia no discurso científico.

Michel Foucault, em A Arqueologia do Saber, lança algumas proposições, dentre as quais, destacamos a primeira: "A ideologia não exclui a cientificidade. Poucos discursos deram tanto lugar à ideologia quanto o discurso clínico ou o da economia política: não é uma razão suficiente para apontar erro, contradição, ausência de objetividade no conjunto de seus enunciados"7 .

Se por um lado, a ideologia acaba comparecendo em nosso fazer científico, por outro, não podemos limitar-nos a um único ponto de vista. A abertura dialética de confrontação entre idéias diferentes deve marcar nossa reflexão. Daí a necessidade de se conhecer correntes teóricas e de se evitar um discurso dogmático, doutrinário de quem traz verdades, acabadas, indiscutíveis. Quando convicções se tornam absolutas, inquestionáveis e impermeáveis a outras leituras da realidade, o conhecimento acaba ocupando uma condição utilitária para o discurso ideológico. $\mathrm{O}$ compromisso que o pesquisador tem com determinada verdade não pode ser limitador, castrador de sua reflexão, que impeça uma constante oxigenação das leituras que vêm desde outros pontos de vista.

O estudo da comunicação e da educação deve acontecer numa perspectiva dialética e plural; onde estas e outras disciplinas compareçam de maneira despojada de suas especificidades e exclusividades no estudo de uma problemática que cruza diferentes âmbitos do conhecimento: a construção e a difusão do saber. Está em ordem, portanto, a interdisciplinaridade em seu sentido mais largo, que supere a dicotomia entre forma e conteúdo, entre tecnologia e ideologia ao articular comunicação e educação. Elas devem ser vistas em suas interconexões, tratadas na dimensão híbrida de uma "educomunicação", como sugere Ismar de Oliveira Soares, autor de um dos artigos desta edição de Distance \& Savoirs.

\section{Um Contexto de Globalização}

Vivemos atualmente a intensificação do processo de globalização. É nesse contexto que fazemos e pensamos comunicação e educação. Uma globalização que se configura em várias direções e dimensões. Bem mais do que o campo da economia, ela se estende em uma globalização política, tecnológica e cultural.

\footnotetext{
${ }^{7}$ Michel Foucault, A Arqueologia do Saber, p. 210.
} 
A globalização econômica cada dia se apresenta mais explícita e impactante. As relações existentes entre os diferentes setores da economia mundial ficam evidentes na influência do movimento das bolsas de valores espalhadas pelos diversos continentes no dia-a-dia das economias locais. Exemplos disso foram a crise do mercado imobiliário dos EUA, ocorrida em 2008, e a recente crise de endividamento da Grécia. Ambas com repercussões em escala planetária. Vivemos em um mundo sem fronteiras, onde o grande capital é internacionalizado e movimenta-se pelo globo com grande rapidez; embora essa movimentação não se traduza, lamentavelmente, em uma efetiva distribuição de riquezas.

Essa globalização econômica é determinante no jogo de poder e influencia as relações internacionais. Ela se projeta, portanto, no plano político, configurando assim uma globalização política. Também se expressa em globalização tecnológica, na medida em que se fortalecem as interdependências dos mercados e dos processos produtivos, padronizando conceitos de qualidade e procedimentos organizacionais, estruturados em sistemas que demandam compatibilidades tecnológicas. A partir dessas transformações, podemos observar também um processo de globalização cultural, onde costumes, comportamentos e valores vão sendo estandartizados nos diferentes cantos alcançados pelo processo de globalização.

Vale reafirmar, no entanto, que esse processo de globalização não alcança a todos de maneira equilibrada, numa justa distribuição de bens e riquezas. Tampouco, o acesso ao mercado e à própria informação se encontra democratizado. As distâncias entre os mais ricos e os mais pobres seguem existindo e, em muitos casos, se ampliam.

Assumindo uma postura crítica em relação ao tema, Milton Santos argumenta que o que existe é o "globaliterismo, uma mistura de globalização com totalitarismo". Ele adverte que: "Quanto mais a globalização se aprofunda, impondo regulações verticais novas a regulações horizontais preexistentes, tanto mais forte é a tensão entre globalidade e localidade, entre o mundo e o lugar" 7 . Num mundo onde a fórmula toma o lugar da forma em razão das demandas do mercado e onde as dinâmicas locais se esvaziam frente ao padrão global determinado, é necessária a constituição de uma postura de preservação da localidade. Precisamos valorizar a "biodiversidade cultural”, preservando a vida, que está na cultura assim como na natureza.

Para compreender a cultura em tempos de globalização, a partir de uma visão crítica e criativa da realidade, é preciso que comunicação e educação sejam pensadas para além das concepções instrumentais e funcionais, que as concebem em uma relação entre forma e conteúdo. 


\section{Mais que informação: comunicação}

A comunicação ocupa lugar de destaque nessa sociedade globalizada, como elemento estruturante. E, neste sentido, seu estudo passa a interessar a diferentes áreas do conhecimento. A comunicação - vista aqui de maneira articula à informação, sem distinção entre forma e conteúdo - acaba sendo, de certa forma, a mola propulsora da organização da vida em sociedade. Isso nos leva a revisitar as idéias de McLuhan. Após um período de certo ostracismo, o polêmico pensador canadense está de volta aos debates acadêmicos. No entanto, por mais fascinante que seja observar que ser humano e tecnologias estão cada vez mais entrosados e pensar "os meios de comunicação como extensões do homem"- como propõe McLuhan - falta muito para que conformemos, de fato, uma "aldeia global", onde todos participem que maneira eqüitativa dos benefícios da tecnologia.

$\mathrm{Na}$ "sociedade em rede", como denomina Manuel Castells, convivemos com a superinformação e a desinformação. Há certo descompasso entre quantidade e qualidade. Vivemos a superação das barreiras de tempo e espaço no fluxo das informações, que se dá em grande velocidade e alcança grandes dimensões geográficas. Elas não chegam em muitos lugares onde o subdesenvolvimento ainda é a realidade para milhões de pessoas. O volume de informações disponíveis é enorme; mas não conseguimos dar conta delas no nosso dia-a-dia. As distâncias físicas são superadas; embora as econômicas, políticas e culturais são mantidas e, mesmo, alargadas.

Podemos dizer que em meio a essa superinformação, de novas dimensões do aparato da informática, vivemos a desinformação, certa alienação e apatia. Edgar Morin conceitua subinformação, superinformação e pseudo-informação ${ }^{8}$. A superinformação é fácil de ser compreendida, sub-informação diz respeito àqueles que estão à margem do processo. Mas, a pseudo-informação é complexa, pede um diálogo entre ciência e filosofia, pois implica no próprio questionamento sobre o sentido e a razão de ser da informação, sobre suas origens e o seu destino.

Nestes tempos de multimídias, de "convergências tecnológicas", a quantidade se sobrepõe à qualidade. Estamos vivendo uma situação de excesso de informação, de poluição de informação. Frente a essa quantidade de informações, sob diferentes formas de linguagens e

\footnotetext{
${ }^{8}$ Edgar Morin, Para Sair do Século XX, p. .
} 
enfoques, nós nem sempre conseguimos condições para refletir, para fruir essas informações, de forma a produzir sentidos que façam sentido na nossa existência individual e coletiva. Uma grande quantidade de estímulos visuais e sonoros, verbais e não-verbais, nos impacta a cada dia e nos provoca um estresse mental e emocional. Muitas informações repetidas ao estremo se tornam banais e perdem o seu sentido. Dá-se, assim, um embate entre quantidade e qualidade, uma desencontro entre forma e conteúdo.

Nesse contexto há uma preocupação exagerada com o universo das técnicas, com o domínio das ferramentas. $\mathrm{E}$ isso ocorre freqüentemente na formação de comunicadores e educadores. Na perspectiva da Sociologia, podemos dizer que ocorre uma priorização da infraestrutura, em detrimento da superestrutura. Dessa maneira, a tecnologia, o método, acaba se sobrepondo aos sujeitos da comunicação/educação: educadores e educandos, interlocutores. Pouco se leva em conta a realidade das transformações da sociedade, das relações de poder, da evolução histórica. Omite-se, assim, uma abordagem mais integral da realidade e do ser humano. Com isso, vamos nos tornando mais mecanicistas, mais pragmáticos, deixando de lado o universo de sonhos, das utopias, deixando de lado a essência do fazer comunicacional e pedagógico, que implicam em processos de interação.

O superdesenvolvimento tecnológico, acompanhado do subdesenvolvimento social, nos desafia a pensar desde uma perspectiva pedagógica em todas as esferas da vida em sociedade. A educação, tão importante para a superação de muitas de nossas fragilidades, não pode ficar restrita aos muros da escola, à lógica da construção sistematizada e hierarquizada de conhecimentos. A aprendizagem se dá a todo tempo e em diferentes dimensões, que não apenas no plano da razão. Trata-se de uma dinâmica complexa e permanente de formação individual e coletiva, que se dá de maneira não-linear, envolvendo diferentes níveis de percepção e apreensão de informações e valores. Para além do plano dedutivo, os processos de aprendizagem ganham dimensões indutivas e, até mesmo, intuitivas. E tal quadro se intensifica no contexto tecnológico contemporâneo, que se estrutura na forma de redes, permitindo a interconexão em larga escala.

Hoje, mais que antes, precisamos encarar o ser humano em sua pluralidade, em sua condição multidimensional. Na obra Para sair do Século XX, Edgard Morin nos adverte para a necessidade da ciência resgatar o ser humano em sua plenitude, não somente na concepção racional, mas também como alguém que faz, sonha e se diverte. Ele diz: 


\begin{abstract}
Vamos partir do homem. Ele é concebido como homo sapiens e homo faber. Ambas as definições são redutoras e unidimensionais. Portanto, o que é demens - o sonho, a paixão, o mito - e o que ludens - o jogo, o prazer, a festa - são excluídos de homo, ou, no máximo, considerados como epifenômenos. O sentimento, o amor, a brincadeira, o humor passam a não Ter mais lugar, senão secundário ou contingente, em todas as visões controladas pelo paradigma de homo sapiens / faber.

[...]

Precisamos superar a noção de homem técnico (homo faber), associado a ela, indissoluvelmente, a de homem imaginativo (que imaginas, sonha, cria fantasmas, mitifica). Precisamos superar a noção de homo sapiens com a noção homo sapiens / demens, que é a única que permite considerar a capacidade que tem o homo sapiens de produzir poesia e arte, sonho e delírio, loucura e horror; ela é a única a nos tornar capazes de compreender que a loucura pode ser produtora de virtudes e sabedoria ${ }^{9}$.
\end{abstract}

É nessa condição de entendimento do ser humano em sua multidimensionalidade, tomado não somente em sua individualidade, mas como um ser coletivo, social, que propomos o diálogo entre comunicação e educação.

\title{
A Dimensão Pedagógica da Comunicação
}

A formação do conhecimento contemporâneo se dá para além da educação formal, numa dinâmica de múltiplas mediações sociais. Expressiva porção dos conteúdos formativos assimilados pelas pessoas é absorvida através dos meios de comunicação de massa e de comunicação em rede. Com o crescimento do aparato tecnológico no cotidiano das grandes cidades, observa-se uma presença cada vez mais intensa da comunicação na vida das pessoas. Em especial, as novas gerações têm seus valores, opiniões e atitudes sedimentadas por veículos que não se interessam propriamente em sua educação, que não assumem explicitamente seu caráter pedagógico, mas que acabam freqüentemente por influenciar mais profundamente a juventude que a educação desenvolvida na escola. A comunicação coloca-se, assim, no espaço da educação informal, que ocorre nas dinâmicas sociais do dia-a-dia onde o indivíduo se vê em interação com seus pares e com as manifestações culturais e informativas com que se depara.

A própria legislação brasileira, na Lei de Diretrizes e Bases da Educação Nacional reconhece a amplitude da dinâmica educativa, registrando em seu artigo primeiro: "A educação abrange os processos formativos que se desenvolvem na vida familiar, na convivência humana,

\footnotetext{
${ }^{9}$ Edgar Morin, Para Sair do Século XX, p. 113.
} 
no trabalho, nas instituições de ensino e pesquisa, nos movimentos sociais, nas organizações da sociedade civil e nas manifestações culturais"10.

Diferentemente de outros momentos em que havia um processo gradativo do envolvimento das pessoas com os meios que estavam ao seu redor, vemos hoje a agilidade e naturalidade com que as crianças e jovens se relacionam com essas novas tecnologias. Esses novos recursos estão presentes em casa, na escola, no trabalho e nos espaços de lazer. Sua presença na vida contemporânea vai tomando contornos de multimídia, uma vez que se vê ampliada a integração de linguagens, num sistema que envolve recursos da informática, da televisão, do rádio, do telefone, incrementando uma nova lógica de acesso e relacionamento com a informação.

Já há algumas décadas Abraham Moles chamava a atenção para a nova dinâmica da formação da cultura:

\begin{abstract}
O papel da cultura é fornecer as percepções do indivíduo, com respeito ao mundo exterior, uma tela de conceitos sobre a qual ele projeta e situa suas percepções. Esta tela conceitual tinha, na cultura tradicional (cartesiana) uma estrutura reticular racional, organizada de uma forma quase geométrica. (...) A cultura moderna que chamamos de "mosaico", oferece-nos uma tela de referência similar a uma série de fibras colocadas ao acaso: umas longas, outras curtas, umas espessas, outras finas, coladas em uma desordem total.

(...)

Atualmente o conhecimento não mais se estabelece, em sua parte principal, pela educação, sendo feito pelos mass-media (meios de comunicação de massa). A tela de nossa cultura não é mais uma rede alinhada com traços principais e traços secundários, uma espécie de tecido ou teia de aranha. Fragmentos de pensamento agregam-se uns aos outros, à mercê da vida de todos os dias, que nos prodigaliza um fluxo constante de informações. Este fluxo nos submerge: na realidade escolhemos, ao acaso na massa de mensagens que se derrama sobre nós. Doravante, esta tela assemelhar-se-á mais ao que se chama um feltro, isto é, a reunião de pequenos elementos de conhecimento, fragmentos de significação. ${ }^{11}$
\end{abstract}

É nesse emaranhado de informações, advindas de várias partes, em diferentes formados e densidades, que o aparato comunicacional se apresenta à sociedade contemporânea como elemento marcante no âmbito da formação individual e coletiva. E o faz de forma híbrida, ao sobrepor elementos de informação e entretenimento, de realidade e ficção, de trabalho e diversão. Tudo ocorre de maneira difusa, onde fragmentos de informações são encontrados por toda parte,

\footnotetext{
${ }^{10}$ Art. $1^{\circ}$ da Lei Federal $\mathbf{N}^{\mathbf{0}}$ 9.394/96, de 20/12/96 (Lei de Diretrizes e Bases da Educação Nacional)

${ }^{11}$ Abraham Moles, Sociodinâmica da Cultura, pp. 18 e 19.
} 
obrigando-nos a desenvolver novas competências e a experimentar a simultaneidade no lugar da linearidade. E neste quadro é indispensável refletir sobre a educação para a comunicação e sobre a comunicação em sua dimensão pedagógica.

Quando falamos aqui da relação entre comunicação e educação, não queremos tomar uma como forma e outra, como conteúdo. Não podemos limitar essa relação à perspectiva do educador, que muitas vezes olha para a comunicação como a forma do seu fazer pedagógico, preocupando com o domínio das técnicas de comunicação com vistas à melhoria da transmissão de conhecimentos em sala de aula. A comunicação é mais do que um simples instrumento das práticas pedagógicas. Possui, em si mesma, uma dimensão pedagógica. Portanto, não se trata de olhar a comunicação de maneira instrumental. Tal enfoque se constitui em uma limitação de nossa herança funcionalista. Por outro lado, não cabe ao comunicador encarar a educação como mera informação. Não se trata de uma editoria temática do jornalismo. Para ambos faz-se necessário conhecer a outra face da moeda.

$\mathrm{Na}$ abordagem dos processos de aprendizagem, pode-se considerar diferentes níveis de sua ocorrência: educação formal (aquela vivida nos espaços escolares), educação não-formal (realizada em iniciativas de educação institucional e popular, em espaços extra-escolares) e educação informal (que tem lugar nas práticas cotidianas, de uma maneira quase involuntária). É neste último nível, em especial, que a comunicação adquire uma dimensão pedagógica.

É justamente neste plano da educação informal, das mediações e intermediações socioculturais do cotidiano que se realizam nas práticas de comunicação, que a sabedoria se abre ao espaço lúdico e ao sonho do ser humano. Manifestações comunicacionais, como as canções populares, os contos e anedotas, os jogos e brincadeiras de rua, as histórias em quadrinhos e os desenhos animados, podem ser motivadas pela intuição educativa de quem produz / emite a informação; mas, também e sobretudo, pela intuição de quem as recebe e interpreta a partir de seus referenciais cotidianos e mediações socioculturais.

Maria Tereza Quiroz, da Universidade de Lima, argumenta que "a explosão tecnológica torna a comunicação particularmente importante na formação da consciência, modos de pensar, atitudes e opiniões dos sujeitos (...) Daí resulta necessário conhecer como se conforma o universo cultural, o conhecimento, o modo de percepção do mundo por parte desses sujeitos, com a 
finalidade de facilitar uma educação que rompa os limites institucionais e crie condições para a expressão livre, ativa, criativa e participativa dos mais jovens". ${ }^{12}$

A pesquisadora peruana sustenta que:

\begin{abstract}
Por muitas razões a comunicação está definitivamente associada à educação. De um lado, porque as modernas técnicas educativas, que são elaboradas como respostas à crise da instituição escolar, colocam em evidência a necessidade de intercâmbio comunicativo entre o professor e o aluno, entre a escola e a realidade. De outro, porque os meios de comunicação e seu suporte tecnológico, somados às possibilidades da informática, ampliam as possibilidades educativas. Também, porque o conhecimento da realidade não provém exclusivamente do texto escrito e porque os mais jovens se educam em maior medida fora da escola. Seus referenciais de conhecimento, suas imagens, seus valores e suas expectativas guardam estreita relação com a comunicação e suas mensagens. 13
\end{abstract}

A formação dos seres humanos nas sociedades contemporâneas passa muito pelas mediações culturais presentes no lugar social no qual eles estão presentes. A produção de sentido em relação às mensagens que eles recebem não estão contidas nos meios tecnológicos que as transportam, mas nas mediações que envolvem o processo de recepção. A esse respeito, o espanhol-colombiano Jesús Martín-Barbero propõe um deslocamento "dos meios às mediações". Essas mediações levam a interpretação dos textos para o campo dos contextos onde estão inseridos os receptores e valem tanto para a comunicação interpessoal, como para a comunicação grupal e massiva e ampliam com a incrementação de novas tecnologias da chamada "era digital".

\title{
Educação: Transmitir ou compartilhar?
}

Para discutir a interseção de comunicação e educação, é necessário perguntar: de que comunicação e educação estamos falando? Algumas correntes pedagógicas têm tomado o processo educacional de maneira a colocar o receptor, o educando, não como um mero receptáculo das informações passadas. Também no campo da comunicação algumas teorias a tomam como algo que não está limitado à ação do emissor, à transmissão da mensagem,

\footnotetext{
${ }^{12}$ María Teresa Quiroz, "Educar en la Comunicación / Comunicar em la Educación", in Revista Diálogos de la Comunicación $\mathbf{N}^{\mathbf{0}}$ 37, p. 38.

${ }^{13}$ María Teresa Quiroz, "Educar en la Comunicación / Comunicar em la Educación", in Revista Diálogos de la Comunicación $\mathbf{N}^{\mathbf{0}}$ 37, p. 54.
} 
entendendo o processo comunicativo como uma relação de troca, onde as partes envolvidas compartilham a mensagem e a produção de sentidos.

Por mais que esse discurso já venha de longos tempos no Brasil, sobretudo de Paulo Freire, o fato é que em nosso dia-a-dia acabamos reproduzindo o modelo que muitas vezes criticamos, em que a educação é uma repetição de verdades para um grupo de meros ouvintes de quem depois vai ser cobrada a assimilação dos conteúdos transmitidos.

Nesse sentido, parece que não nos convencemos do processo de construção do conhecimento como uma relação dinâmica de troca, em que o educador e o educando interagem no processo pedagógico. Caso contrário, já teríamos condições mais favoráveis para essa prática educativa, que extrapola a mera passagem de conjunto de conceitos de um pólo para o outro, rompendo com o modelo tradicional de escola apoiada na passagem do conhecimento. Precisamos investir num fazer pedagógico mais participativo, buscando condições para que isso se efetive.

Se, por um lado, o educador acaba limitando a prática pedagógica, na concreta efetivação do seu trabalho, a uma atividade meramente de transmissão, no plano da comunicação nós encontramos esse mesmo enfoque, num reflexo invertido. O comunicador acaba olhando para a educação de uma forma utilitária onde ele pretende passar de forma fiel a informação desejada. Ao atuar na grande imprensa ou no universo das comunicações e marketing, ele acaba fazendo uso de todos os recursos de linguagem e persuasão para direcionar aquela informação ao seu receptor, tomado como um sujeito passivo no processo da comunicação. Por mais que se discuta a interlocução, o processo de participação do receptor, o fato é que observamos uma lógica quase sempre unidirecional do processo comunicativo.

Reflete-se, assim, aquela lógica da educação bancária também vivida no espaço da educação formal. No caso da comunicação, busca-se a superação de ruídos, de interferências, na busca de uma construção cada vez mais linear e eficaz na transmissão da informação. Há um desprezo da condição do receptor que acaba comparecendo apenas como um elemento coadjuvante no processo da comunicação, enquanto o protagonista é o emissor. Dá-se grande importância ao aparato comunicacional, à produção da comunicação, enquanto que a recepção acaba sendo relegada a um segundo plano. Até mesmo na formação do profissional de comunicação acaba ocorrendo um enfoque bastante pragmático, com ênfase nas competências 
técnicas, o que caracteriza a instrumentalização do conhecimento em prol da comunicação cada vez mais eficaz.

Faz-se necessário compreender o receptor (educando) como sujeito do seu processo de aprendizagem. Superar o enfoque utilitário da comunicação tomada como transmissão de informações, compreendendo seu caráter dialógico, entendendo que comunicar é compartilhar, é tornar comum idéias e sentimentos.

No confronto das duas concepções do termo comunicações - transmitir e compartilhar podemos resgatar a condição do receptor como sujeito do processo comunicativo. Desta forma poderemos compreender a comunicação não somente a partir do enfoque da mensagem constituída, mas também através da análise dos processos de recepção, da fruição.

Maria Tereza Cruz adverte para o fato de que não podemos estar voltados somente para a poíesis (poética), para a produção da mensagem; mas que devemos estar atentos para a aisthesis (estética), para o plano da recepção da mensagem, geralmente relegado a um plano secundário ${ }^{14}$. Nessa condição da descoberta do plano da aisthesis, da recepção, resgata-se o papel do receptor não mais como um receptáculo, um elemento passivo, como coadjuvante, ou somente mais um número do processo de comunicação. Ao trazermos essa participação ao plano da fruição, ele também acaba criando, atribuindo novas significações, sentidos para as mensagens que está recebendo. A atenção se volta para a interação entre o receptor e a mensagem, onde efetivamente ocorre a produção dos sentidos. Rompe-se, assim, com a idéia de que o sentido está contido na mensagem e que deve ser descoberto pelo receptor num processo linear de decodificação.

Nesse ponto encontramos a possibilidade da interseção com uma educação que cruza com a comunicação. Já não mais tomando o educando que está ali só para aprender ou, por outro lado, tomando o comunicador como o que tudo tem a dizer e o receptor somente como a quem cabe entender e adequadamente decodificar o que foi a ele proposto, sobretudo alguém que deve responder adequadamente aos estímulos propostos.

Precisamos, portanto, resgatar esse educando e esse receptor. É nessa ótica que resgatamos o que é comunicação e o que é educação. Se assim o fazemos, essa interseção tornase não só tensa e bastante importante, como o estudo dessa interseção vai se constituir num objeto primordial para os estudos científicos de nosso tempo. Ao resgatar a figura desse receptor, desse

\footnotetext{
${ }^{14}$ Maria Tereza Cruz, "A Estética da Recepção e a Crítica da Razão Impura", in Revista de Comunicação e Linguagem $\mathbf{N}^{\mathbf{3}} 3$ (Portugal), p.57
} 
educando, nós acabamos transpondo o estudo da comunicação do plano da mensagem, do texto, para o plano do contexto. A atenção, até então centrada na mensagem ou nos meios de comunicação, com separação entre conteúdo e forma, volta-se para as relações do cotidiano, para as mediações que marcam o processo de interpretação da mensagem por parte do receptor. Tratase das referências, motivações e expectativas que estão entre - no meio - a mensagem e o receptor, das condições em que ocorre o processo de fruição. Isso pode ser observado na sala de aula, onde as relações de atenção e apreensão dos temas tratados dependem de múltiplos fatores, que passam pela história de vida do educando, por sua condição de sexo, raça e religião, por suas condições socioeconômicas, pelas referências de seu grupo de convivência e de identidade e pela própria proposta pedagógica e condição de infra-estrutura da escola.

É nesse plano que podemos encontrar e compreender a dimensão pedagógica da comunicação, como instância transformadora da realidade. Quando praticada não mais como instrumento de manipulação e persuasão, ela passa a ser trabalhada como um espaço onde o emissor não é mais o único protagonista da realidade que se desenvolve. Agora também o receptor ganha uma importância de quem tem capacidade de criar e atribuir novos sentidos à mensagem proposta.

\section{Comunicação e educação: além de forma e conteúdo}

Cabe ao educador e ao comunicador a valorização do ser humano que está na condição de receptor e o investimento em sua formação crítica, a fim de que ele possa aprender e se apropriar, como sujeito, dos conhecimentos desenvolvidos. É vital e urgente, na formação do comunicador, incorporar sua conscientização da faceta educativa da sua atividade, dentro de uma ética da emissão e de uma estética da recepção.

Em tempos de comunidades de apropriação mantidas através da rede internacional de computadores e das experiências - cada vez mais bem-sucedidas - de educação a distância, já não cabe separar essas duas esferas da vida em sociedade; tampouco, manter os padrões tradicionais da concepção unidirecional da comunicação e da educação, onde receptores e alunos são tomados como "público alvo" a ser atingido. Deveras, o educando deve ser sujeito de sua aprendizagem, mais que objeto de manipulação; assim como o receptor dos discursos da mídia 
deve ser mais que um mero receptáculo, já que ele realiza uma interpretação da mensagem recebida, produzindo novos sentidos.

Comunicação é mais do que instrumento do fazer educacional. Ela própria, como vimos, tem uma dimensão pedagógica e pode ser pensada no campo da educação informal. E o conhecimento que se constrói através da interação com a comunicação, em seus diferentes meios e linguagens, pode ser desenvolvido sob o signo da liberdade. Nele, a dinâmica da indução, que se estabelece pela intermediação de várias informações, supera os procedimentos dedutivos que são predominantes na educação formal.

María Tereza Quiroz salienta:

A escola ofereceu sempre o saber formalizado, organizado, hierarquizando, no qual se cresce por etapas, através do ensino que implica mecanismos de comprovação dos esforços e do rendimento. O "saber" oferecido pelos meios massivos rompeu com as categorias intelectuais tradicionais próprias do sistema escolar, de modo que flui desordenadamente, sem autoridades aparentes. Além do mais, este saber está estreitamente vinculado ao entretenimento e livre de toda obrigação e avaliação. Se aproveitou do velho divórcio que a escola auspiciou entre conhecimento e entretenimento, identificando-se com este segundo pólo, que, de longe, desperta maior interesse nas crianças e jovens, estimulando sua imaginação. 15

Por outro lado, é indispensável que se tome como um dos objetivos da educação a formação de cidadãos capazes de compreender criticamente a realidade social, que se desenvolve por meio de uma leitura crítica da comunicação, numa confrontação dos receptores com os produtos dos emissores, a partir do contexto em que se encontram os próprios receptores intérpretes. É preciso impelir o público a controlar as múltiplas possibilidades de interpretação das mensagens que recebe.

Nesse sentido, Umberto Eco adverte:

Um partido político que saiba atingir minuciosamente os grupos que assistem a televisão levando-os a discutir a mensagem que recebem, pode mudar o significado que a Fonte atribuíra a essa mensagem. Uma organização educativa que conseguisse fazer um determinado público discutir a mensagem que está recebendo, poderia inverter o significado dessa mensagem. Ou mostrar que a mensagem pode ser interpretada de diversos modos. Reparem: não estou propondo uma nova e mais terrível forma de controle de opinião pública. Estou propondo uma ação para impelir o público a controlar a mensagem e suas múltiplas possibilidades de interpretação. ${ }^{16}$

\footnotetext{
${ }^{15}$ María Teresa Quiroz, Todas las Voces: Comunicación y Educación en el Peru, p. 30.

${ }^{16}$ Umberto Eco, Viagem na Irrealidade Cotidiana, p. 174.
} 
Talvez tal proposta, voltada à constituição de uma educação crítica para a apreensão das mensagens difundidas pelos meios de comunicação, soe como algo ingênuo, um tanto utópico. Mas o fato é que vivemos numa sociedade de consumo, de meios de comunicação de massa, de cultura industrializada. E nesse contexto não basta lamentar e denunciar a dominação que se dá através da manipulação das massas; não se trata do fim da cultura, do apocalipse. Tampouco, convém integrar-se no sistema que aí está, de maneira ingênua ou resignada, como mão de obra especializada a serviço de uma comunicação e de uma educação massificante e autoritária.

É necessária a emancipação da recepção, como um espaço de criação, de produção de sentidos e saberes; bem como, a descoberta do educando, como alguém que tem algo a dizer. Por certo, sua fala estabelecerá conexões entre saberes advindos de distintas esferas de seu cotidiano e suas relações com seus pares, próximos ou distantes, com os quais convive em espaços físicos ou virtuais. No momento em que ele puder se expressar, tomando posse do conhecimento apreendido, numa ação de comunicação, estarão sendo constituídos nexos consistentes entre educação e comunicação.

\section{Bibliografia}

ABREU JUNIOR, Laerthe. Conhecimento Transdisciplinar: O Cenário Epistemológico da Complexidade. Piracicaba, Unimep, 1996.

CRUZ, Maria Teresa. "A Estética da Recepção e a Crítica da Razão Impura", in Revista de Comunicação e Linguagem $\mathrm{N}^{\mathrm{o}} 3$ (Portugal).

DESCARTES, René. Discurso Sobre o Método, São Paulo, Hemus, 1978.

ECO, Umberto. Viagem na Irrealidade Cotidiana, $8^{a}$ ed., Rio de Janeiro, Nova Fronteira, 1984.

FOUCAULT, Michel. A Arqueologia do Saber, $3^{a}$ ed., Rio de Janeiro, Forense-Universitária, 1987. HEGEL, George W. F. Introdução à História da Filosofia. São Paulo, Hemus, 1983.

MARTIN-BARBERO, Jesús. De los Medios a las Mediaciones (comunicación, cultura y hegemonia), México, G. Gilli, 1987.

MCLUHAN, Marshall. Os Meios de Comunicação como Extensões do Homem, São Paulo, Cultrix, 1979.

MORAGAS SPA, Miguel de. Teorias de la Comunicación. $3^{a}$ ed., Barcelona (Espanha), G. Gilli, 1985. MOLES, Abraham. Sociodinâmica da Cultura, São Paulo, Perspectiva, 1974.

MORIN, Edgar. O Método III: O Conhecimento do Conhecimento. $2^{a}$ ed., Mem Martins (Portugal), Europa-América, 1987. 
REVISTA AÇÃOMIDIÁTICA - Estudos em Comunicação, Sociedade e Cultura

Universidade Federal do Paraná

Programa de Pós Graduação em Comunicação Vol I. No 1. Ano 2011

Para Sair do Século XX. Nova Fronteira, Rio de Janeiro, 1986.

QUIROZ, María Teresa. Educar en la Comunicación / Comunicar en la Educación, in Diálogos de la Comunicación $\mathrm{N}^{\circ}$ 37, Lima, FELAFACS, 1993.

1993.

. Todas las Voces: Comunicación y Educación en el Perú, Lima, Universidad de Lima, 